\title{
Effect of level of protein intake and of age of rat on the biological value of proteins
}

\author{
By KATHLEEN M. HENRY AND S. K. KON \\ National Institute for Research in Dairying, Shinfield, near Reading
}

(Received I I Fanuary 1957)

Mitchell \& Beadles (I950) have reported a very low biological value of $5^{\mathbf{I}}$ for casein, determined with adult rats at 2 and $4 \%$ levels of protein intake. They compared this value with one of 69 , obtained with young rats, quoted by Block \& Mitchell (1946-7) and considered that their low value reflects an increased requirement by the adult rat for the sulphur amino-acids. No support for this view was found in this laboratory, where biological values of 83 and 9 r were obtained for dried skim milk with young and adult rats respectively, at a $4 \%$ level of protein intake (Henry \& Kon, 1952). Milk and casein are equally deficient in methionine, but the cystine deficiency is more marked in the latter (Block \& Mitchell, I946-7); this difference seemed a possible explanation for the conflicting results in the two laboratories. We, therefore, made tests on young rats with casein, alone or supplemented with methionine, at 4 and $8 \%$ levels of protein intake, and repeated the experiment on the same rats when adult. Another aspect of changes, with age, in the amino-acid requirements of the rat was studied in similar experiments with a sample of stored, deteriorated dried skim milk in which the lysine had been partly inactivated by the Maillard reaction (cf. Henry, Kon, Lea \& White, I947-8).

It has long been established, both in growth (Osborne, Mendel \& Ferry, 1919) and nitrogen-balance studies (Mitchell, $1923-4 b$ ) that the utilization of protein is affected by its dietary level. To obtain further information on this subject, and provide a background to our studies in this laboratory, the biological value of two high-quality proteins, egg and casein, was determined at several levels of intake on young rats.

The results of some other experiments with young rats, primarily planned in connexion with a different problem, where the biological values of casein and of soya-bean meal were determined at 8 and $16 \%$ levels of protein intake, are also reported.

\section{EXPERIMENTAL}

\section{Animals and technique}

In all experiments the biological value and true digestibility of the proteins were determined by the method of Mitchell (Mitchell, 1923-4a; Mitchell \& Carman, 1926). Each experiment was done with three litters of four female rats (hooded Norwegian of our own breeding); each rat received each diet in turn according to a Latin-square design. Details of the feeding and management of the rats are given in our earlier publications (Henry, Kon \& Watson, r937; Henry et al. 1947-8); in Exps. 3, 4 and 7 
the periods of collection of excreta were reduced from 6 to 4 days (cf. Henry \& Kon, I956). The basal diet had the following percentage composition: rice starch 64, sugar I2, potato starch Io, margarine fat 10, salts (de Loureiro, I93I) 4. The protein source to be tested was added in place of an equal weight of rice starch. Table I gives, for all experiments, the source of protein tested, the amount of it included in the diets and the nitrogen content of the diets.

Table I. Quantity and source of protein and percentage of nitrogen in the experimental diets

Level of dietary protein $(\%)$

\begin{tabular}{|c|c|c|c|c|c|}
\hline \multirow{2}{*}{$\begin{array}{l}\text { Exp. } \\
\text { no. }\end{array}$} & \multicolumn{2}{|c|}{$\overbrace{}^{(\%)}$} & \multirow[b]{2}{*}{ Description } & \multirow{2}{*}{$(\%)$} & \multirow{2}{*}{$\begin{array}{l}\mathrm{N} \text { in } \operatorname{diet} \\
(\%)\end{array}$} \\
\hline & Intended & Actual* & & & \\
\hline I & $\begin{array}{l}4 \\
8\end{array}$ & $\begin{array}{l}4 \cdot I \\
8 \cdot I\end{array}$ & $\begin{array}{l}\text { Casein I (vitamin-free, Glaxo } \\
\text { Laboratories, Ltd) }\end{array}$ & $\left\{\begin{array}{l}4 \cdot 2 \\
8 \cdot 5\end{array}\right.$ & $\begin{array}{l}0.649 \\
x \cdot 265\end{array}$ \\
\hline & $\begin{array}{l}4 \\
8\end{array}$ & $\begin{array}{l}4 \cdot 1 \\
7 \cdot 5\end{array}$ & \} Casein I $+0.4 \%$ DL-methionine & $\begin{array}{l}4 \cdot 2 \\
8 \cdot 5\end{array}$ & $\begin{array}{l}0.648 \\
x \cdot 183\end{array}$ \\
\hline 2 & $\begin{array}{l}4 \\
8\end{array}$ & $\begin{array}{l}3 \cdot 5 \\
7 \cdot 0\end{array}$ & $\left\{\begin{array}{l}\text { Dried skim milk, high-moisture, } \\
\text { stored at } 37^{\circ} \text { for } 60 \text { days }\end{array}\right.$ & $\begin{array}{l}10 \cdot 6 \\
21 \cdot 8\end{array}$ & $\begin{array}{l}0.548 \\
I \cdot 097\end{array}$ \\
\hline & $\begin{array}{l}4 \\
8\end{array}$ & $\begin{array}{l}4 \cdot 7 \\
7 \cdot 5\end{array}$ & $\left\{\begin{array}{l}\text { Dried skim milk, high-moisture, } \\
\text { stored at } 37^{\circ} \text { for } 60 \text { days, }+1 \cdot 25 \% \\
\text { L-lysine }\end{array}\right.$ & $\begin{array}{l}10 \cdot 9 \\
22 \cdot 3\end{array}$ & $\begin{array}{l}0.738 \\
x \cdot 173\end{array}$ \\
\hline 3 & $\begin{array}{r}4 \\
8 \\
12 \\
\text { I } 6\end{array}$ & $\begin{array}{r}3 \cdot 3 \\
7 \cdot 4 \\
11 \cdot 3 \\
15 \cdot 4\end{array}$ & Ether-extracted whole dried egg & $\begin{array}{r}4 \cdot 4 \\
10 \cdot 0 \\
16 \cdot 0 \\
21 \cdot 8\end{array}$ & $\begin{array}{l}0.524 \\
I \cdot 155 \\
I \cdot 763 \\
2 \cdot 4 I I\end{array}$ \\
\hline 4 & $\begin{array}{r}4 \\
8 \\
12 \\
16\end{array}$ & $\begin{array}{r}5 \cdot 0 \\
8 \cdot 6 \\
13 \cdot 0 \\
17 \cdot 0\end{array}$ & $\begin{array}{l}\text { Casein IV (low-vitamin, Genatosan } \\
\text { Ltd) }\end{array}$ & $\begin{array}{r}4 \cdot 5 \\
9 \cdot 3 \\
14 \cdot 1 \\
18 \cdot 9\end{array}$ & $\begin{array}{l}0 \cdot 783 \\
1 \cdot 355 \\
2 \cdot 022 \\
2 \cdot 730\end{array}$ \\
\hline 5 & $\begin{array}{r}8 \\
x 6\end{array}$ & $\begin{array}{r}7 \cdot 5 \\
15 \cdot 1\end{array}$ & $\begin{array}{l}\text { Casein II (low-vitamin, Genatosan } \\
\text { Ltd) }\end{array}$ & $\begin{array}{r}8 \cdot 6 \\
17 \cdot 5\end{array}$ & $\begin{array}{l}x \cdot 170 \\
2 \cdot 314\end{array}$ \\
\hline & $\begin{array}{r}8 \\
16\end{array}$ & $\begin{array}{r}7 \cdot 1 \\
14 \cdot 4\end{array}$ & Soya-bean meal I & $\begin{array}{l}14 \cdot 8 \\
29 \cdot 4\end{array}$ & $\begin{array}{l}I \cdot 14 I \\
2 \cdot 298\end{array}$ \\
\hline 6 & $\begin{array}{r}8 \\
16\end{array}$ & $\begin{array}{r}7 \cdot 4 \\
14 \cdot 9\end{array}$ & $\left\{\begin{array}{l}\text { Casein II (low-vitamin, Genatosan } \\
\text { Ltd) }\end{array}\right.$ & $\begin{array}{r}8 \cdot 6 \\
17 \cdot 5\end{array}$ & $\begin{array}{l}r \cdot 162 \\
2 \cdot 335\end{array}$ \\
\hline & $\begin{array}{r}8 \\
16\end{array}$ & $\begin{array}{r}7 \cdot 4 \\
17 \cdot 2\end{array}$ & Soya-bean meal II & $\begin{array}{l}16 \cdot 3 \\
33 \cdot 1\end{array}$ & $\begin{array}{l}I \cdot 187 \\
2 \cdot 748\end{array}$ \\
\hline 7 & $\begin{array}{r}8 \\
16\end{array}$ & $\begin{array}{r}8 \cdot 9 \\
18 \cdot 2\end{array}$ & \} $\begin{array}{l}\text { Casein III (low-vitamin, Genatosan } \\
\text { Ltd) }\end{array}$ & $\begin{array}{r}9.4 \\
19.0\end{array}$ & $\begin{array}{l}I \cdot 398 \\
2 \cdot 85 I\end{array}$ \\
\hline & $\begin{array}{r}8 \\
16\end{array}$ & $\begin{array}{r}8 \cdot 8 \\
17 \cdot 8\end{array}$ & Soya-bean meal III & $\begin{array}{l}\text { I } 8 \cdot 6 \\
37 \cdot 9\end{array}$ & $\begin{array}{l}I \cdot 414 \\
2 \cdot 846\end{array}$ \\
\hline
\end{tabular}

* These values were calculated by multiplying the actual nitrogen content of the diet by the conventional protein factors: 6.38 for milk and casein, 6.25 for soya-bean meal. In referring to protein levels in the text the 'intended' levels are used for simplicity.

\section{Design of experiments}

Effect of level of intake, young and adult rats

Exp. I. Casein. 'Vitamin-free' casein (Glaxo Laboratories Ltd) with or without a supplement of $0.4 \%$ DL-methionine was tested at 4 and $8 \%$ levels of protein intake 
on rats at $\mathrm{I}$ month of age and again with the same rats at 5 months; between experiments the rats were given our stock diet (Folley, Ikin, Kon \& Watson, 1938).

Exp. 2. Milk. Stored dried skim milk (cf. Henry \& Kon, 1952) with or without a supplement of $\mathrm{x} \cdot 25 \%$ L-lysine was tested in the same way as casein in Exp. I.

Effect of level of intake, young rats

Exp. 3. Egg. Ether-extracted whole dried egg was tested at protein levels of about $4,8,12$ and $16 \%$.

Exp. 4. Casein. This experiment was as Exp. 3 but with low-vitamin casein (Genatosan Ltd).

Exps. 5-7. Casein and soya-bean meal. Casein and soya-bean meal were tested at 8 and $16 \%$ protein levels. In Exps. 5 and 6 vitamin-free casein (Glaxo Laboratories Ltd) and in Exp. 7 low-vitamin casein (Genatosan Ltd) were used. The samples of heat-treated soya-bean meal obtained from U.S.A. differed in all three experiments.

\section{RESULTS}

Exp. I. Effect of level of protein intake and of age of rat on the biological value and true digestibility of casein, alone or supplemented with $0.4 \%$ DL-methionine

The results are given in Table 2 . With the young rats the biological values were the same whether there was 4 or $8 \%$ of the protein in the diet, whereas with the adult animals significantly higher values were found at the lower level. In all tests methionine increased the biological value of casein, but the increase was significant only for the young rats at the $8 \%$ level. In comparison with young rats, adults gave significantly higher values at the $4 \%$ and significantly lower values at the $8 \%$ level of intake. Only small differences were found between the true digestibilities, some being just significant.

Table 2. Exp. I. Effect of addition of $0.4 \%$ DL-methionine on the biological value and true digestibility of casein determined at 4 and $8 \%$ levels of protein intake on young rats and on the same rats when adult

\begin{tabular}{|c|c|c|c|c|c|}
\hline \multirow{2}{*}{$\begin{array}{l}\text { Level of } \\
\text { protein } \\
\text { intake } \\
(\%)\end{array}$} & \multirow[b]{2}{*}{ Addition to casein } & \multicolumn{2}{|c|}{ Biological value } & \multicolumn{2}{|c|}{ True digestibility } \\
\hline & & $\begin{array}{c}\text { Young } \\
\text { rats }\end{array}$ & $\begin{array}{l}\text { Adult } \\
\text { rats }\end{array}$ & $\begin{array}{l}\text { Young } \\
\text { rats }\end{array}$ & $\begin{array}{c}\text { Adult } \\
\text { rats }\end{array}$ \\
\hline $\begin{array}{l}4 \\
8\end{array}$ & None & $\begin{array}{l}76 \cdot 5 \\
72 \cdot 7\end{array}$ & $\begin{array}{l}84 \cdot 6 \\
60 \cdot 5\end{array}$ & $\begin{array}{l}96 \cdot 4 \\
97 \cdot 9\end{array}$ & $\begin{array}{l}97 \cdot 4 \\
96 \cdot 7\end{array}$ \\
\hline $\begin{array}{l}4 \\
8\end{array}$ & $0.4 \%$ DL-methionine & $\begin{array}{l}80 \cdot 5 \\
8 I \cdot 1\end{array}$ & $\begin{array}{l}87 \cdot 7 \\
65 \cdot 2\end{array}$ & $\begin{array}{l}99 \cdot 3 \\
98 \cdot 6\end{array}$ & $\begin{array}{l}98 \cdot 6 \\
96 \cdot 8\end{array}$ \\
\hline \multicolumn{2}{|c|}{ Standard error of the mean ( 36 D.F.) } & \multicolumn{2}{|c|}{$\pm \mathrm{I} \cdot 78$} & \multicolumn{2}{|c|}{ \pm 0.63} \\
\hline
\end{tabular}

Exp. 2. Effect of level of protein intake and of age of rat on the biological value and true digestibility of the proteins of a deteriorated sample of dried skim milk, alone or supplemented with $\mathrm{I} \cdot 25 \%$ L-lysine

The results are given in Table 3 . They are broadly similar to those obtained in Exp. I and in our earlier experiments with milk (Henry \& Kon, 1952). With the 
young, but not with the adult, rats lysine increased the biological value of the deteriorated milk, but the increase was statistically significant only at the $8 \%$ protein level.

At the $4 \%$ level significantly higher values were found with adult than with young rats. Again differences in the true digestibility of the milks were slight; the value for the lysine-supplemented milk at the $4 \%$ level with adult rats was significantly higher than any of the other values.

Table 3. Exp. 2. Effect of addition of $\mathrm{1} \cdot 25 \%$ L-lysine on the biological value and true digestibility of the proteins of deteriorated dried skim milk determined at 4 and $8 \%$ levels of protein intake on young rats and on the same rats when adult

\begin{tabular}{|c|c|c|c|c|c|}
\hline \multirow{3}{*}{$\begin{array}{l}\text { Level of } \\
\text { protein } \\
\text { intake } \\
(\%)\end{array}$} & \multicolumn{5}{|c|}{ (Groups of twelve rats) } \\
\hline & & \multicolumn{2}{|c|}{ Biological value } & \multicolumn{2}{|c|}{ True digestibility } \\
\hline & Addition to milk & $\begin{array}{l}\text { Young } \\
\text { rats }\end{array}$ & $\begin{array}{l}\text { Adult } \\
\text { rats }\end{array}$ & $\begin{array}{l}\text { Young } \\
\text { rats }\end{array}$ & $\begin{array}{l}\text { Adult } \\
\text { rats }\end{array}$ \\
\hline $\begin{array}{l}4 \\
8\end{array}$ & None & $\begin{array}{l}84 \cdot 5 \\
64 \cdot 8\end{array}$ & $\begin{array}{l}94.8 \\
76.6\end{array}$ & $\begin{array}{l}85 \cdot 4 \\
82 \cdot 9\end{array}$ & $\begin{array}{l}88 \cdot 4 \\
86 \cdot 0\end{array}$ \\
\hline $\begin{array}{l}4 \\
8\end{array}$ & I.25\% L-lysine & $\begin{array}{l}88.9 \\
85.8\end{array}$ & $\begin{array}{l}95 \cdot 2 \\
73 \cdot 4\end{array}$ & $\begin{array}{l}87 \cdot 3 \\
85 \cdot 2\end{array}$ & $\begin{array}{l}93 \cdot 4 \\
87 \cdot 0\end{array}$ \\
\hline \multicolumn{3}{|c|}{ Standard error of the mean 3} & & \multicolumn{2}{|c|}{ $\pm I \cdot 4 I$} \\
\hline
\end{tabular}

Exp. 3. Effect of level of protein intake on the biological value and true digestibility of the proteins of egg

The results are shown in Table 4 . The biological value of whole-egg proteins was, statistically, the same at 4 and $8 \%$ levels of protein intake; it decreased progressively, and highly significantly, when the protein level was further increased to 12 and $16 \%$. The true digestibility of the egg proteins was significantly lower at I 6 than at 4,8 and I $2 \%$; with the three lower levels the small differences were not significant.

Table 4. Exp. 3. Effect of level of protein intake on the biological value and true digestibility of egg proteins determined on young rats

$\begin{array}{ccc}\begin{array}{c}\text { Level of } \\ \text { (Groups of twelve rats) } \\ \text { protein intake } \\ (\%)\end{array} & \begin{array}{c}\text { Biological } \\ \text { value }\end{array} & \begin{array}{c}\text { True } \\ \text { digestibility }\end{array} \\ 4 & 92.9 & 98.3 \\ 8 & 93.7 & 97.8 \\ \text { I2 } & 83.2 & 97.2 \\ \text { I6 } & 67.0 & 95.5 \\ \text { Standard error } & \pm 8.53 & \pm 0.53 \\ \text { of the mean } & 1.53 & \\ \text { (17 D.F.) } & & \end{array}$

Exp. 4. Effect of level of protein intake on the biological value and true digestibility of casein

The results are given in Table 5. The biological value of casein determined at a $4 \%$ level of protein intake did not differ significantly from the $8 \%$ value, but increasing the protein level to 12 and $16 \%$ caused a progressive, and highly significant, fall. The true digestibility was not affected by the level of protein intake. 
Table 5. Exp. 4. Effect of level of protein intake on the biological value and true digestibility of casein determined on young rats

\begin{tabular}{|c|c|c|}
\hline \multicolumn{3}{|c|}{ (Groups of twelve rats) } \\
\hline $\begin{array}{l}\text { Level of } \\
\text { protein intake } \\
(\%)\end{array}$ & $\begin{array}{l}\text { Biological } \\
\text { value }\end{array}$ & $\begin{array}{c}\text { True } \\
\text { digestibility }\end{array}$ \\
\hline 4 & $82 \cdot 9$ & 99.1 \\
\hline 8 & $8 \mathrm{I} \cdot 3$ & 99.5 \\
\hline 12 & $75 \cdot 2$ & $99 \cdot 3$ \\
\hline I6 & $66 \cdot 7$ & $99 \cdot 3$ \\
\hline $\begin{array}{l}\text { Standard error } \\
\text { of the mean } \\
\text { (I } 8 \text { D.F.) }\end{array}$ & $\pm \mathrm{I} \cdot 88$ & $\pm 0.3^{6}$ \\
\hline
\end{tabular}

Exps. 5-7. Effect of level of protein intake on the biological value and true digestibility of casein and of soya-bean meal

The results are shown in Table 6 . In all three experiments significantly higher biological values were found for casein at the 8 than at the $16 \%$ level of protein. For soya-bean meal, in Exps. 5 and 6, the level of protein intake had no effect on its biological value; in Exp. 7, however, the value was significantly higher at the lower level of intake.

The true digestibility of casein or of soya-bean meal was not affected by the level of protein intake in any of the experiments.

Table 6. Exps. 5-7. Biological value and true digestibility of casein and of the proteins of soya-bean meal determined on young rats at 8 and $16 \%$ levels of intake

\begin{tabular}{|c|c|c|c|c|c|c|c|}
\hline \multirow[b]{2}{*}{ Protein source } & \multirow{2}{*}{$\begin{array}{l}\text { Level of } \\
\text { protein } \\
\text { intake } \\
(\%)\end{array}$} & (Grou & of twelv & ats) & \multicolumn{3}{|c|}{ True digestibility } \\
\hline & & Exp. 5 & Exp. 6 & Exp. 7 & Exp. 5 & Exp. 6 & Exp. 7 \\
\hline $\begin{array}{l}\text { Casein } \\
\text { Casein } \\
\text { Soya-bean meal } \\
\text { Soya-bean meal }\end{array}$ & $\begin{array}{r}8 \\
\times 6 \\
8 \\
r 6\end{array}$ & $\begin{array}{l}65 \cdot 5 \\
55 \cdot 7 \\
55 \cdot 3 \\
54 \cdot 7\end{array}$ & $\begin{array}{l}67 \cdot 9 \\
47 \cdot 6 \\
59 \cdot 7 \\
60 \cdot 9\end{array}$ & $\begin{array}{l}80 \cdot 1 \\
64 \cdot 6 \\
72 \cdot 9 \\
64 \cdot 3\end{array}$ & $\begin{array}{l}98 \cdot 5 \\
98 \cdot 7 \\
85 \cdot 1 \\
84 \cdot 8\end{array}$ & $\begin{array}{l}97 \cdot 1 \\
97 \cdot 5 \\
89 \cdot 7 \\
89 \cdot 6\end{array}$ & $\begin{array}{l}99 \cdot 1 \\
98 \cdot 5 \\
89 \cdot 6 \\
88 \cdot 5\end{array}$ \\
\hline $\begin{array}{l}\text { Standard error of the } \\
\text { mean (18 D.F.) }\end{array}$ & & $\pm \mathrm{I} \cdot 44$ & $\pm \mathrm{I} \cdot 28$ & $\pm 1 \cdot 97$ & \pm 0.36 & $\pm \mathrm{I} \cdot 00$ & \pm 0.37 \\
\hline
\end{tabular}

\section{DISCUSSION}

Reports in the literature (Frost, 1950; Mitchell, 1950; Forbes \& Yohe, 1955) indicate that, in terms of percentage of the total nitrogen intake, the requirements of young and adult rats for the sulphur amino-acids are essentially the same. However, Womack, Harlin \& Lin (r953) have shown that a higher proportion must be supplied as methionine to the young $(5 / 6)$ than to the adult (I/3) rat (see also Hartsook $\&$ Mitchell, 1956). Mitchell (1947) and Mitchell \& Beadles (1950) interpreted earlier findings in their laboratory as indicating an increased requirement by the adult rat for these acids, but in a very recent publication Hartsook \& Mitchell (1956) reversed this view and concluded that the least amount of both protein and the sulphur amino-acids necessary 
for the maintenance of nitrogen equilibrium decreases with age. Our results (Exp. I) agree with this conclusion. As with milk (Henry \& Kon, 1952), we obtained a significantly higher biological value (85) for casein with adult rats at the $4 \%$ protein level than with young rats at either the 4 (77) or $8 \%(73)$ levels. Moreover, with the adults a supplement of methionine did not significantly increase the biological value of casein at either level of intake, a finding that indicates a decrease in their needs for the sulphur amino-acids.

Our experiments (Exp. 2 and Henry \& Kon, 1952), support the conclusions of Neuberger \& Webster (1945), Mitchell (1947) and Nasset \& Ely (1952) that the adult rat requires less lysine than the young growing animal. The high biological value now obtained with adult rats for the lysine-deficient sample of milk (see above) at a $4 \%$ level of intake agrees with that found earlier for the same sample of milk (Henry \& Kon, 1952). Addition of lysine had no effect either at the $4 \%$ or at the $8 \%$ level of intake. With young rats, on the other hand, a supplement of $\mathrm{r} \cdot 25 \% \mathrm{~L}$-lysine increased the biological value of this milk at both levels of intake though not significantly so at the $4 \%$ level. We would have expected that the improvement would be significant also at the $4 \%$ level since in earlier experiments (Henry \& Kon, 1952) the biological value of the control milk in which lysine was fully available was at both levels higher than that of the deteriorated sample. Earlier experiments at an $8 \%$ level (Henry et al. I947-8) had shown that the biological value of a similarly stored sample of milk could be brought to that of the control milk by the addition of $\mathrm{I} \cdot 25 \% \mathrm{~L}$-lysine but that the addition of excess lysine depressed the value (see also Henry \& Kon, 1952). A possible explanation of the discrepancy between these tests is that as the experimental design did not allow us now to include a sample of the control milk in the tests we do not know to what extent the lysine supplement made good the lysine deficiency of the stored milk.

No change was found in the biological value of egg (Exp. 3) or casein (Exps. I and 4) when the protein level was increased from 4 to $8 \%$ but for both proteins the value progressively decreased when the protein concentration was further increased to 12 and $16 \%$ (Exps. 3 and 4 ). This finding is in general agreement with the conclusions of Mitchell \& Beadles (1952) that rats use protein more efficiently for growth at dietary levels below $12 \%$.

Our results, summarized in Table 7 , indicate that any decreases in the biological value in the change from the 4 to the $8 \%$ level may be a function of the protein tested. Thus for a complete protein (egg) or for one deficient mainly in methionine (casein) the biological values did not differ significantly. However, when the principal deficiency was of lysine, biological values were markedly higher at the $4 \%$ level. Mitchell $(1923-4 b)$ obtained lower values at to than at $5 \%$ for several proteins, but noted that the decrease was much more marked with cereal than with milk proteins.

Lysine is essential for growth in the young rat but much less so for the adult (Neuberger \& Webster, 1945; Mitchell, I947; Nasset \& Ely, 1952). It follows, therefore, that if a young rat fails to grow, its requirement for lysine will correspond more closely to that of the adult and a high biological value indicating no shortage of lysine will result. Our records show that young rats given the lysine-deficient milk 
(Exp. 2 and Henry \& Kon, 1952) just maintained their weight at the $4 \%$ level but that at $8 \%$ they made slow but appreciable gains. Thus it is evident that if certain proteins are tested on young rats at too low a dietary level, amino-acid deficiencies, that are evident at higher levels, may be undetected and spuriously high biological values may

Table 7. Effect of level of protein intake and of amino-acid deficiencies in proteins on their biological value determined on young rats

\begin{tabular}{|c|c|c|c|c|}
\hline Protein source & $\begin{array}{l}\text { Level of } \\
\text { protein } \\
\text { intake } \\
(\%)\end{array}$ & $\begin{array}{l}\text { Biological } \\
\text { value }\end{array}$ & Limiting amino-acid & Reference \\
\hline Egg & $\begin{array}{l}4 \\
8\end{array}$ & $\left.\begin{array}{l}93 \\
94\end{array}\right\}$ & None & This work \\
\hline Casein (Exp. I) & $\begin{array}{l}4 \\
8\end{array}$ & $\begin{array}{l}77 \\
73\end{array}$ & Methionine & \\
\hline Casein (Exp. 4) & $\begin{array}{l}4 \\
8\end{array}$ & $\begin{array}{l}83 \\
81\end{array}$ & Methionine & \\
\hline Casein $+0.4 \%$ methionine & $\begin{array}{l}4 \\
8\end{array}$ & $\begin{array}{l}8 \mathrm{r} \\
8 \mathrm{I}\end{array}$ & $?$ & \\
\hline Dried skim milk & $\begin{array}{l}4 \\
8\end{array}$ & $\begin{array}{l}83 \\
85\end{array}$ & Methionine & Henry \& Kon (1952) \\
\hline Stored dried skim milk & $\begin{array}{l}4 \\
8\end{array}$ & $\begin{array}{l}71 \\
59\end{array}$ & Lysine and methionine & \\
\hline Stored dried skim milk & $\begin{array}{l}4 \\
8\end{array}$ & $\begin{array}{l}85 \\
65\end{array}$ & Lysine and methionine & This work \\
\hline $\begin{array}{l}\text { Stored dried skim milk }+ \\
\text { I.25\% lysine }\end{array}$ & $\begin{array}{l}4 \\
8\end{array}$ & $\left.\begin{array}{l}89 \\
86\end{array}\right\}$ & Methionine & \\
\hline
\end{tabular}

be obtained for proteins deficient in one or more of the essential amino-acids. This may be an explanation for the lack of effect of methionine and lysine supplements respectively on the biological values of casein (Exp. I) and stored milk (Exp. 2) at the $4 \%$ level of intake. It seems, therefore, that in tests with young rats a protein level that allows reasonable growth $(8-10 \%)$ should prove the most satisfactory in the determination of the biological value of proteins.

We have pointed out in earlier publications (Henry et al. 1947-8; Henry \& Kon, 1956) the advisability of including some reference protein in all balance experiments since responses may vary markedly with different batches of rats. This need is further emphasized by the results of Exps. 5-7 (Table 6). Thus at the 8\% level the biological values of both casein and soya were markedly lower in Exps. 5 and 6 than in Exp. 7, although the relative values of these two proteins were similar in all three experiments. In twenty-seven separate experiments at the same level we obtained a mean biological value of 80 for five different samples of low-vitamin casein, a value of the same order as those reported in the literature (cf. Kon \& Henry, I95 I, I954). The values of 66 and 68 now found for casein II (Exps. 5 and 6) are not only lower than our mean but are also the lowest of nine values (mean 79 ) obtained before and since for this particular sample of casein. For four samples of soya-bean meal we have found (unpublished results) a mean biological value of $7 \mathrm{I}$ in eleven separate experiments. The value of 73 found for soya III (Exp. 7) agrees well with this mean value but those of 55 and 60 respectively found for soyas I (Exp. 5) and II (Exp. 6) are very much lower. 
A decrease in biological value with increase of the dietary protein from 8 to $16 \%$ would be expected for high-quality animal and vegetable proteins like casein and soya-bean meal. A fairly consistent decrease was observed for casein in the four experiments now reported. In three of them (Exps. 4, 5 and 7) and in earlier work (Henry \& Kon, 1956) we found that the $16 \%$ values were $15-18 \%$ lower than those determined at $8 \%$; in the remaining experiment (Exp. 6) the decrease was $30 \%$.

The results for soya were less consistent, and the increase in protein level depressed the biological value only in Exp. 7; in the other two experiments the values were almost identical at the two levels. No explanation can be offered for these findings.

\section{SUMMARY}

I. The effect of level of protein intake on the biological value and true digestibility of several proteins was studied in experiments with young rats; some of the experiments were repeated with the same rats when adult.

2. A higher biological value was found for casein with adult rats at a $4 \%$ than at an $8 \%$ level of protein intake or than at either level of intake with the same rats when young.

3. The addition of $0.4 \%$ DL-methionine increased significantly the biological value of casein only with the young rats at the $8 \%$ level of intake.

4. These results suggest that the sulphur amino-acid requirement of the rat decreases with age.

5. The biological value of a sample of lysine-deficient dried skim milk (cf. Henry et al. $1947-8)$ was significantly higher for adult rats at a $4 \%$ than at an $8 \%$ level of protein intake or than for the same rats when young at either level of intake: this finding is consistent with the lower lysine requirement of the adult rat.

6. With the young rats a significantly higher value was found for the deteriorated sample at the 4 than at the $8 \%$ level of intake.

7. A supplement of $\mathrm{I} \cdot 25 \% \mathrm{~L}$-lysine to the deteriorated sample increased significantly the biological value of the milk only for young rats at the $8 \%$ level of intake.

8. With young rats increase of the level of protein intake from 4 to $8 \%$ did not change significantly the biological value of egg proteins or of casein. With both, further increases to 12 and $16 \%$ caused a progressive decrease in their biological value.

9. It is suggested that if young rats fail to gain weight adequately on diets containing low levels of proteins deficient in one or more of the essential amino-acids spuriously high biological values may be obtained. In general, tests with $8 \%$ protein in the diet should be more reliable guides to the relative nutritive value of proteins than tests done at lower levels.

Io. The advisability of including a reference protein in nitrogen-balance experiments is stressed.

II. With the proteins studied, differences in true digestibility with changes in level of protein intake or age of rat were small, some being just significant.

Our thanks are due to Mrs M. R. Hussey for help with the nitrogen analyses and to Miss M. V. Chapman for help with feeding the rats. 


\title{
REFERENCES
}

Block, R. J. \& Mitchell, H. H. (1946-7). Nutr. Abstr. Rev. 16, 249.

de Loureiro, A. (193I). Arch. Pat., Lisboa, 3, 72.

Folley, S. J., Ikin, E. W., Kon, S. K. \& Watson, H. M. S. (1938). Biochem. F. 32, I988.

Forbes, R. M. \& Yohe, M. (1955). F. Nutr. 55, 499.

Frost, D. V. (1950). In Protein and Amino Acid Requirements of Mammals, p. 33. [A. A. Albanese, editor.] New York: Academic Press Inc.

Hartsook, E. W. \& Mitchell, H. H. (1956). F. Nutr. 6o, I73.

Henry, K. M. \& Kon, S. K. (1952). F. Dairy Res. I9, 216.

Henry, K. M. \& Kon, S. K. (1956). Brit. F. Nutr. ro, 39.

Henry, K. M., Kon, S. K., Lea, C. H. \& White, J. C. D. (1947-8). F. Dairy Res. 15, 292.

Henry, K. M., Kon, S. K. \& Watson, M. B. (1937). Milk and Nutrition, Part I, p. 37. Reading: National Institute for Research in Dairying.

Kon, S. K. \& Henry, K. M. (195 I). F. Dairy Res. 18, 317.

Kon, S. K. \& Henry, K. M. (1954). F. Dairy Res. 21, 245.

Mitchell, H. H. (1923-4a). F. biol. Chem. 58, 873 .

Mitchell, H. H. $(1923-4 b)$. F. biol. Chem. 58, 905 .

Mitchell, H. H. (1947). Arch. Biochem. 12, 293.

Mitchell, H. H. (1950). In Protein and Amino Acid Requirements of Mammals, p. 1. [A. A. Albanese, editor.] New York: Academic Press Inc.

Mitchell, H. H. \& Beadles, J. R. (1950). F. Nutr. 40, 25.

Mitchell, H. H. \& Beadles, J. R. (1952). Э. Nutr. 47, I 33.

Mitchell, H. H. \& Carman, G. G. (1926). f. biol. Chem. 68, 183.

Nasset, E. S. \& Ely, M. T. (I952). F. Nutr. 48, 39 I.

Neuberger, A. \& Webster, T. A. (1945). Biochem. F. 39, 200.

Osborne, T. B., Mendel, L. B. \& Ferry, E. L. (1919). F. biol. Chem. 37, 223.

Womack, M., Harlin, H. A. \& Lin, P.-H. (I953). Y. Nutr. 49, 513 .

\section{Vitamin $B_{12}$ and methyl-group synthesis}

\author{
By B. CONNOR JOHNSON,* E. S. HOLDSWORTH, \\ J. W. G. PORTER AND S. K. KON \\ National Institute for Research in Dairying, Shinfield, near Reading
}

(Received 14 fanuary 1957)

Work with vitamin $\mathrm{B}_{12}$-deficient and normal baby pigs has shown that vitamin $\mathrm{B}_{12}$ takes no part in transmethylation from choline or betaine to homocysteine or homocystine to form methionine (Mistry, Firth \& Johnson, 1955; Firth, Mistry, James \& Johnson, 1954) or in the conversion of glycine to serine (Chang \& Johnson, 1955), but that vitamin $B_{12}$ is required for methyl synthesis from glycine and from serine (Johnson, Firth \& Mistry, I955; Chang \& Johnson, 1955; Johnson \& Mistry, I955).

Thus it was shown that the place of vitamin $\mathrm{B}_{12}$ in methionine formation is similar in the pig to that established in the rat (Arnstein \& Neuberger, I953; Stekol, Weiss, Smith \& Weiss, I953; Henry \& Kon, 1956) for methyl synthesis, although it differs

* John Simon Guggenheim Memorial Foundation Fellow, on leave of absence from the Division of Animal Nutrition, University of Illinois, U.S.A. 